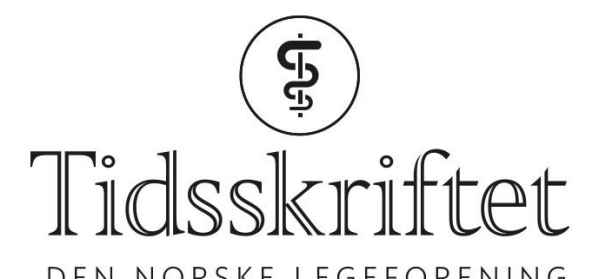

DEN NORSKE LEGEFORENING

\title{
Bruk av uspesifikke diagnosekoder på legevakt
}

KORT RAPPORT

\section{HOGNE SANDVIK}

E-post: hogne.sandvik@uib.no

Nasjonalt kompetansesenter for legevaktmedisin

NORCE Norwegian Research Centre

Bergen

Hogne Sandvik er dr.med., spesialist i allmennmedisin, fastlege ved Morvik legekontor i Bergen og forsker.

Forfatteren har fylt ut ICMJE-skjemaet og oppgir ingen interessekonflikter.

\section{STEINAR HUNSKÅR}

Nasjonalt kompetansesenter for legevaktmedisin

NORCE Norwegian Research Centre

Bergen

Institutt for global helse og samfunnsmedisin

Universitetet i Bergen

Steinar Hunskår er dr.med., spesialist i allmennmedisin, professor i allmennmedisin og seniorforsker. Forfatteren har fylt ut ICMJE-skjemaet og oppgir ingen interessekonflikter

\section{BAKGRUNN}

Primærlegene setter diagnosekoder på alle regningskort. Formålet med studien var å kartlegge bruk av uspesifikke diagnosekoder som kan svekke validiteten av statistikk og sykdomsovervåkning.

\section{MATERIALE OG METODE}

Materialet består av data fra alle elektroniske regningskort fra legevaktleger i perioden 2008-19. Vi registrerte konsultasjoner og telefonkontakter og hvor stor andel av disse som ble kodet med diagnosekoder for luftveisinfeksjoner og med tre uspesifikke diagnosekoder.

\section{RESULTATER}

Antall konsultasjoner per år økte fra 1402452 i 2008 til i 1417395 i 2019, en relativ økning på 1\%. Antall telefonkontakter per år økte fra 286515 i 2008 til 684773 i 2019, en relativ økning på $139 \%$. Legevaktkontakter kodet med uspesifikke diagnoser økte nesten 13 ganger, fra 40280 til 514715 . Bruk av uspesifikke diagnoser $ø$ kte 19 ganger ved telefonkontakter og 2,7 ganger ved konsultasjoner. Samlet antall legevaktkontakter med luftveisinfeksjoner avtok fra 240037 til 176909 (26\% reduksjon). 
Det er en sterk tendens til at generelle, uspesifikke diagnosekoder erstatter spesifikke sykdomsdiagnoser på regningskort fra legevakt. Dette svekker grunnlaget for statistikk og forskning basert på innrapporterte ICPC-2-diagnoser, og er spesielt bekymringsfullt når disse diagnosene skal brukes til overvåkning av covid-19-pandemien.

I 1992 fastsatte Rikstrygdeverket at primærleger skal bruke ICPC (International Classification of Primary Care) for koding av diagnoser på legeregningskort og sykmeldinger. Hensikten var å få et enhetlig system for koding av diagnoser. Norge var dermed det første landet som gjorde ICPC til en offisiell nasjonal standard. Siden 2004 har man brukt oppfølgeren ICPC-2 (1).

ICPC er basert på en bokstavkode for organsystem, inkludert egne bokstavkoder for allmenne tilstander, psykiske og sosiale problemer, etterfulgt av en tosifret kode for nærmere kategorisering. Tallkodene oo-29 angir symptomer og plager, mens 70-99 angir diagnoser og sykdommer. Diagnosekoden for lungebetennelse består for eksempel av bokstaven R for sykdom i luftveiene og tallkoden 81 .

Det første tilfellet av covid-19-infeksjon ble påvist i Norge 26. februar 2020. Det antas at det er store mørketall, fordi mange smittede har lette symptomer og aldri vil bli testet. For å få en bedre oversikt over utbredelsen vil man derfor også bruke diagnosedata fra primærlegenes elektroniske pasientjournaler, inkludert legevakt (2). I forbindelse med covid-19-pandemien er det innført nye diagnosekoder: R991 (mistenkt eller sannsynlig covid-19-infeksjon) og R992 (bekreftet covid-19 infeksjon)(2).

Nasjonalt kompetansesenter for legevaktmedisin har i mange år utarbeidet statistikk basert på regningskortene fra legevakt (3). Vi er etter hvert blitt bekymret over en tiltakende bruk av uspesifikke diagnoser, særlig ved telefonkontakter. I 2018 fikk 65,6\% av alle telefonkontaktene en av tre slike diagnosekoder: A29 (Generelle symptomer/plager), A97 (Administrativ kontakt/undersøkelse) eller A99 (Helseproblem/sykdom) (3). Bruk av uspesifikke diagnoser svekker muligheten for å bruke slike data til sykdomsovervåkning. Hensikten med denne studien var å analysere trenden i bruk av diagnosekoder for luftveisinfeksjoner og uspesifikke diagnosekoder i perioden 2008-19.

\section{Materiale og metode}

Materialet består av data fra alle elektroniske regningskort som ble levert av legevaktleger i perioden 2008-19, tidligere brukt i utarbeiding av Årsstatistikk fra legevakt (3). Anonymiserte datafiler ble utlevert fra Helfo/Kontroll og utbetaling av helserefusjoner (KUHR). Vi har ikke opplysninger som kan identifisere kommune eller legevakt, heller ikke avlønningsform, men hver enkelt behandler er tildelt et unikt nummer som muliggjør aggregering av takstkoder per lege.

Et $\varnothing$ kende antall legevakter har fastlønnsordning for vaktlegene, noe som har ført til at mange regningskort tidligere er blitt sendt med legevaktens eller kommunens organisasjonsnummer, uten opplysninger om behandlende lege. Fra 2016 skal imidlertid alle regninger inneholde opplysninger om hvem som er utførende behandler. Sykepleiere i legevaktsentraler gir ofte råd til pasienter, men kan ikke lage regningskort i eget navn. Disse telefonkontaktene må derfor knyttes til en identifiserbar lege. Hvordan og i hvilken grad dette gjennomføres i praksis, varierer trolig fra legevakt til legevakt.

Konsultasjoner og sykebesøk (takstkodene 2ad, 2ae, 2ak, 2fk, 11ad eller 11ak, heretter benevnt konsultasjoner) og telefonkontakter (takstkodene 1bd, 1bk, 1be, 1g) er registrert. Samlet antall legevaktkontakter er definert som summen av konsultasjoner og telefonkontakter. Kontakter som var kodet med diagnosekoder for luftveisinfeksjoner (R71-R83) eller tre allmenne, uspesifikke diagnoser (A29, A97 og A99) er inkludert. For hvert år ble det 
beregnet hvor stor andel av alle konsultasjoner eller telefonkontakter disse to diagnosegruppene utgjorde.

Årsstatistikk for legevakt er vurdert av personvernansvarlig i NAV og personvernombudet for forskning (3). Siden det ikke er mulig å identifisere enkeltpersoner i materialet, verken direkte eller indirekte, er prosjektet ikke underlagt meldeplikt etter personopplysningsloven.

Siden materialet omfatter alle elektroniske regningskort og ikke representerer et utvalg, er de påviste forskjellene reelle og ikke beheftet med statistisk usikkerhet. Data presenteres derfor uten konfidensintervall, og det er ikke utført statistiske tester.

\section{Resultater}

Antall konsultasjoner per år økte fra 1402452 i 2008 til i 1417395 i 2019, en relativ $\emptyset$ kning på 1\%. Antall telefonkontakter per år økte fra 286515 i 2008 til 684773 i 2019, en relativ økning på 139\%. Samlet antall legevaktkontakter med luftveisinfeksjoner ble redusert med $26 \%$ fra 240037 til 176 909, mens legevaktkontakter kodet med uspesifikke diagnoser $\emptyset$ kte nesten 13 ganger, fra 40280 til 514715 . Andel luftveisinfeksjoner og uspesifikke diagnoser av alle telefonkontakter er vist i figur 1, og tilsvarende andel av alle konsultasjoner er vist i figur 2. I absolutte tall $\emptyset$ kte bruk av uspesifikke diagnoser ved telefonkontakter 19 ganger, fra 24802 til 473 257. Ved konsultasjoner økte denne 2,7 ganger, fra 15478 til 41458.

- Uspesifikke diagnoser 1 Luftveisinfeksjoner

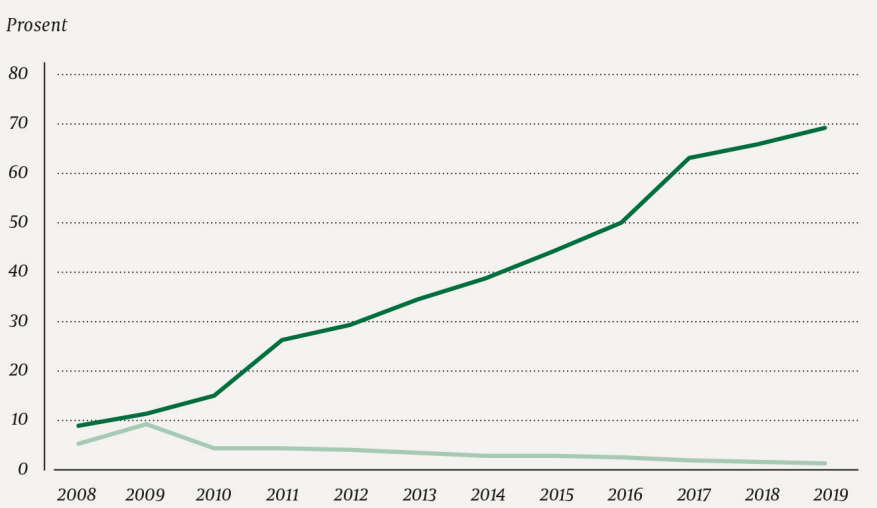

Figur 1 Andel (prosent) av alle telefonkontakter som har fått diagnosekode for luftveisinfeksjon eller en av tre uspesifikke diagnoser (A29, A97, A99).

Uspesifikke diagnoser

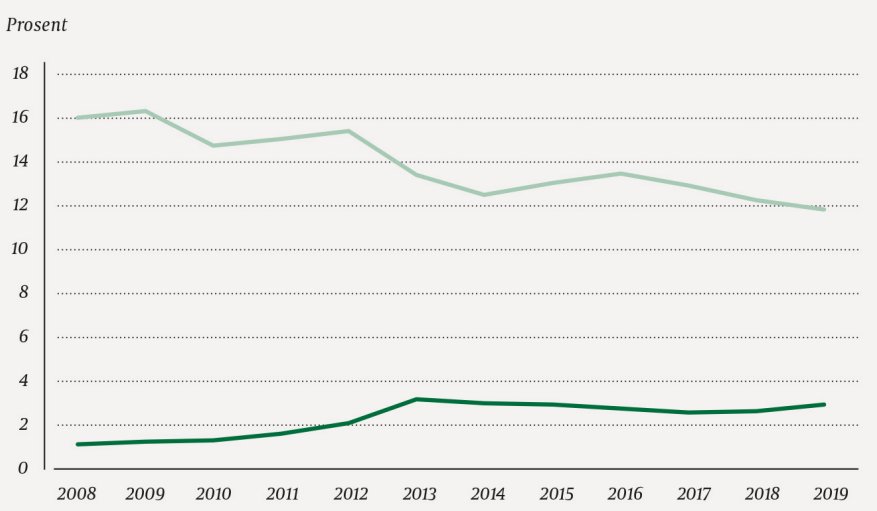

Figur 2 Andel (prosent) av alle konsultasjoner som har fått diagnosekode for luftveisinfeksjon eller en av tre uspesifikke diagnoser (A29, A97, A99).

I 2019 var 14 leger ansvarlig for $45 \%$ av alle regningskort for telefonkonsultasjoner, og av disse var $99 \%$ kodet med uspesifikk diagnosekode. 


\section{Diskusjon}

Denne studien viser at konsultasjonstallet på legevakt er stabilt, mens det er en sterk $\emptyset \mathrm{kning}$ i antall telefonkontakter. Videre er det en sterk $\emptyset$ kning i bruk av uspesifikke diagnosekoder, først og fremst ved telefonkontakter. Parallelt med denne utviklingen er det færre legevaktkontakter som blir registrert som luftveisinfeksjoner.

Trolig har det tidligere vært en underrapportering av telefonkontakter med sykepleier i legevaktsentralen, i den forstand at det ikke har blitt sendt regning for telefonkonsultasjoner. Det er sannsynlig at det nå oftere lages regningskort for slike kontakter. Det høye antallet telefonkontakter for et fåtall leger kan tyde på at det ved enkelte legevakter brukes journalsystem med funksjoner som lager standardiserte regningskort i navnet til en fast lege og med uspesifisert diagnose. Vakttårnprosjektet, som registrerer faktiske telefonkontakter ved sju utvalgte legevakter, finner relativt stabile rater for telefonkontakt (4).

Diagnosekoder ved konsultasjoner settes av leger. Disse viser mindre endringer over tid, men også her ser man en tendens til økende bruk av uspesifikke koder, på bekostning av andre og mer spesifikke diagnoser. I en tidligere studie ble det funnet rimelig god validitet av allmennlegers bruk av ICPC-diagnoser i konsultasjoner, men forfatterne advarte mot å inkludere enkle kontakter i datagrunnlaget for offentlig statistikk (5).

Dersom nåværende kodepraksis fortsetter, vil hyppigheten av luftveisinfeksjoner bli underestimert. Dette er bekymringsfullt i nåværende situasjon, der helsemyndighetene vil overvåke covid-19-pandemien ved hjelp av slike diagnoser innsamlet fra fastleger og legevakter.

Omfanget av uspesifikke diagnoser er allerede så stort at det svekker grunnlaget for statistikk og forskning basert på innrapporterte ICPC-diagnoser. For legekonsultasjoner er omfanget ennå begrenset og muligheten for feiltolkning relativt liten. Men for telefonkontaktene er nivået så høyt at diagnosesystemet i praksis har mistet sin verdi når det gjelder å vise diagnosefordelingen ved telefonkontakter til legevakt. Dette er alvorlig, ikke bare i den aktuelle pandemisituasjonen, men for validiteten av all epidemiologisk forskning som bygger på slike registerdata. Helsedirektoratet bør vurdere å innskjerpe overfor både fastlegene og legevaktene at man skal tilstrebe korrekt bruk av diagnosekoder, unngå uspesifikke diagnosekodene spesielt og avstå fra automatisk generering av diagnosekoder på regningskort.

\section{HOVEDFUNN}

Bruk av uspesifikke diagnosekoder på legevakt øker, særlig ved telefonkontakter. Utviklingen svekker grunnlaget for statistikk basert på innrapporterte diagnosekoder.

\section{LITTERATUR:}

1. Direktoratet for e-helse. ICPC-2. Den internasjonale klassifikasjonen for primærhelsetjenesten. https://ehelse.no/kodeverk/icpc-2.den-internasjonale-klassifikasjonen-for-primaerhelsetjenesten Lest 21.4.2020.

2. Folkehelseinstituttet. Følger med på antall legebesøk for koronavirus. https://www.fhi.no/nyheter/2020/ovrvaker-antall-legebesok-for-koronavirus/ Lest 21.4.2020.

3. Sandvik H, Hunskår S, Blinkenberg J. Årsstatistikk fra legevakt 2018. Rapport nr. 2-2019. Bergen: Nasjonalt kompetansesenter for legevaktmedisin, NORCE Norwegian Research Centre, 2019. http://bora.uib.no/handle/1956/19421 Lest 21.4.2020.

4. Eikeland OJ, Fotland SLS, Raknes G et al. Vakttårnprosjektet. Epidemiologiske data frå legevakt. Samlerapport for 2018. Rapport nr.3-2019. Bergen: Nasjonalt kompetansesenter for legevaktmedisin, 
NORCE, Norwegian Research Centre, 2019. http://bora.uib.no/handle/1956/20536 Lest 21.4.2020.

5. Sporaland GL, Mouland G, Bratland B et al. Allmennlegers bruk av ICPC-diagnoser og samsvar med journalnotatene. Tidsskr Nor Legeforen 2019; 139. doi: 10.4045/tidsskr.18.0440. [PubMed][CrossRef]

Publisert: 3. august 2020. Tidsskr Nor Legeforen. DOI: 10.4045/tidsskr.20.0266

Mottatt 26.3.2020, første revisjon innsendt 21.4.2020, godkjent 6.5.2020.

(C) Tidsskrift for Den norske legeforening 2020. Lastet ned fra tidsskriftet.no 